\title{
On Atriplex canescens (Chenopodiaceae s. str./ Amaranthaceae s. I.) in Tunisia: nomenclatural and morphological notes on its infraspecific variability
}

\author{
Duilio lamonico ${ }^{1}$ (D) \& Ridha El Mokni ${ }^{2}$ (i)
}

Key words: Atriplex, halophytic flora, lectotypification, new record, nomen invalidum, Shenzhen Code.

Ključne besede: Atriplex, halofitska flora, lektotipifikacija, nova nahajališča, nomen invalidum, Shenzhen Kodeks.

Received: 5. 2. 2018

Revision received: 7. 8. 2018

Accepted: 4. 9. 2018

\begin{abstract}
Populations of Atriplex canescens var. gigantea were found in Lamta, BoufichaEnfidha (central Tunisia), and Medenine (southern Tunisia). Literature data concerning the presence of this species in Tunisia are contradictory but now our data confirm its occurrence in the country. On the other hand, this variety is reported in the present paper for the first time both in Tunisia and in North Africa in general. Morphological characters and ecological data are presented, as well as notes about patterns of infraspecific variability of $A$. canescens. Nomenclatural notes on infraspecific names in $A$. canescens, as well as on the closely related species $A$. garrettii, are provided. The types of the names $A$. canescens var. laciniata, A. canescens var. macilenta, A. garrettii, Obione occidentalis var. angustifolia, and Pterochiton occidentale, that in earlier publications were erroneously considered to be holotypes, are in fact lectotypes (for most of taxa) under Art. 9.10 of the ICN. Isolectotypes were found at CAS (A. canescens var. laciniata and A. canescens var. macilenta), GH (A. canescens var. macilenta), and YU (Atriplex nuttallii).

Izvleček

Populacije Atriplex canescens var. gigantea smo našli pri mestih Lamta, BoufichaEnfidha (srednja Tunizija) in Medenine (južna Tunizija). Literaturni podatki o pojavljanju te vrste v Tuniziji so si nasprotujoči, z našimi podatki pa potrjujejmo njeno pojavljanje v tej državi. V članku tudi prvič objavljamo pojavljanje te varietete v Tuniziji in severni Afriki na splošno. Predstavljamo morfološke značilnosti in ekološke podatke in tudi vzorec znotrajvrstne variabilnosti vrste A. canescens. Podajamo nomenklaturne opombe o poimenovanju taksonov na nivoju pod vrsto in tudi ozko sorodne vrste $A$. garrettii. Tipi imen $A$. canescens var. laciniata, $A$. canescens var. macilenta, A. garrettii, Obione occidentalis var. angustifolia in Pterochiton occidentale, ki so jih v predhodnih objavah napačno smatrali kot holotip, so v bistvu lektotipi (za večino taksonov) po členu 9.10 Mednarodnega kodeksa nomenklature. Izolektotipe smo našli v herbarijih CAS (A. canescens var. laciniata in A. canescens var. macilenta), GH (A. canescens var. macilenta) in YU (Atriplex nuttallii).
\end{abstract}




\section{Introduction}

Atriplex L. (Chenopodiaceae; placed in Amaranthaceae s. l. in APG IV 2016), is a genus of about 260 currently recognized species occurring mainly in arid and semiarid regions of Eurasia, America, and Australia (Kühn 1993, Sukhorukov \& Danin 2009, Kadereit et al. 2010, Brignone et al. 2016). The genus is monophyletic if defined so as to include Obione Gaertn., Teutliopsis (Dumort.) Čelak. and some other segregate genera (see, e.g., Kadereit et al. 2010).

The North African flora comprises at least 28 species of Atriplex, of which 15 occur in Tunisia (see Uotila 2011, SANBI 2012). The presence of Atriplex canescens (Pursh) Nutt. in Tunisia appears to be controversial. SANBI (2012), based on Franclet \& Le Houérou (1971), reports this species as present in Tunisia, while Uotila (2011) indicates $A$. canescens in North Africa only from Egypt.

As part of ongoing studies on the nomenclature the of genus Atriplex (see e.g., Iamonico 2012, 2013, Iamonico $\&$ Sukhorukov 2014), and investigations of the Tunisian Flora (e.g., Sukhorukov et al. 2016, Iamonico \& El Mokni 2017), we found a population certainly referable to Atriplex canescens s. l. thereby confirming its presence in Tunisia. Further notes on the nomenclature and taxonomy of this species (that was correctly typified by McNeill et al. 1983: 553) are given.

\section{Materials and methods}

The work is based on an extensive field surveys, analysis of literature, and examination of specimens (about 100) and their digital images from the herbaria: CAS, JEPS, GH, HFLA, NY, RO, US, and YU (acronyms according to Thiers 2018+), and in the personal collection of R. El Mokni deposited in the Herbaria of the Faculty of Pharmacy of Monastir and of the personal Herbarium of El Mokni (not listed in Index Herbariorum, Thiers 2018+).

The articles of the International Code of Nomenclature for algae, fungi, and plants (hereafter abbreviated as ICN) cited throughout the text refer to the Shenzhen Code (Turland et al. 2018).

\section{Results and discussion}

\subsection{Floristic data}

Atriplex canescens is here confirmed as occuring in Central and Southern Tunisia (Lamta, and Bouficha-Enfida localities). In particular, we identified the plants as var. gigantea Welsh \& Stutz (in Welsh 1984: 189), which is a new addition to the Tunisian flora and appears to be the only variety currently occuring in Tunisia.

Atriplex canescens is morphologically similar and related to $A$. garrettii, the species not occurring in Tunisia (Uotila 2011), from which it differs in both vegetative (height of plants, and width of leaf blades) and generative characters (presence of teeth in fruiting bract-like).

\subsection{Nomenclatural notes}

\subsubsection{Atriplex canescens var. laciniata}

Parish (in Jepson 1914: 442) provided a short diagnosis of Atriplex canescens var. laciniata, and also stated the provenance ("Caleb, Colorado Desert... Also occurring in the Mohave Desert") and cited two syntypes: "Parish 8256", and "Jepson 5171a". Consequently (Art. 9.4), lectotypification is necessary, and a lectotype should be selected from the syntypes cited in the protologue.

Welsh \& Crompton (1995: 324), for Atriplex canescens var. laciniata, wrote: "Type: California, Imperial Co., "Plants of Southern California, Salton Basin, Caleb. About 200 feet below sea level. No. 8256. Coll. S. B. Parish. Oct 11. 1911"; holotype UC JEPS!; isotype GH!". Under ICN Art. 9.10, Welsh \& Crompton's use of the term "holotype" is an error to be corrected to lectotype, whereas the GH specimen is an isolectotype. In addition, we traced a third specimen (second isolectotype) at CAS (code 0027906). The indication of "UC JEPS!" in Welsh \& Crompton (1995) can be considerd as citation of a sigle herbarium, not two (JEPS, and UC) [probably it is just an indication that the Jepson Herbarium (JEPS) belongs to the University of California (UC)]. So, no second-step lectotypification is needed.

\subsubsection{Atriplex canescens var. macilenta}

The protologue of Atriplex canescens var. macilenta Parish (in Jepson 1914: 442) consists of a short diagnosis and the citation of one type gathering (syntype, Art. 9.6): "Holtville, Colorado Desert, Parish 8258".

Welsh \& Crompton (1995: 324) reported for Atriplex canescens var. laciniata the following type information: "Type: California, Imperial Co... Plants of Southern California. Salton Basin. Bluffs of Alamo River, Halbartlc. About 15 feet below Sea Level, S. B. Parish 82.'58, Oct 18, 1812"; holotype UC JEPS!; isotypes DS ("Calexico"), CHI, POM!". According to ICN Art. 9.10, Welsh \& Crompton's use of the term "holotype" is an error to be corrected to lectotype, while the DS, CHI, and POM specimens are isolectotypes. In addition, we traced two further isolectotypes at CAS (code 0027907), and GH (code 00036872). As in the previous case indication 
of Atriplex canescens var. laciniata, the indication "UC JEPS!" can be considerd as citation of a sigle herbarium, not two (JEPS, and UC), so no second-step lectotypification is needed.

\subsubsection{Atriplex garrettii s. I.}

Rydberg (1912: 312) described Atriplex garrettii through a detail diagnosis, also comparing the species with A. canescens, A. confertifolia (Torr. \& Frém.) S. Watson (三 Obione confertifolia Torr. \& Frém.), A. occidentalis (Torr. \& Frém.) D. Dietr. (三Pterochiton occidentale Torr. \& Frém.), and A. tetraptera (Benth.) Rybd. (三Obione tetraptera Benth.); moreover, he reported the provenance ("Utah. Vicinity of Moab"), a date ("July 1, 1911"), the collector, the collector number and the herbarium ["Rydberg \& Garrett 8465 (type, in herb. N. Y. Bot. Garden)"].

Sanderson \& Stutz (2001: 78) reported "Type: Valley of the Rio Grande from El Paso to 40 miles below San Elceario, Wright 1742 (lectotype NY).”. According to the Art. 7.11 of ICN "... designation of a type is achieved only ..., on or after 1 January 2001, if the typification statement includes the phrase "designated here" (hic designatus) or an equivalent". As a consequence, the lectotype indication by Sanderson \& Stutz (l.c.) cannot be considered as valid.

Sanderson \& Stutz (2001: 79), and Welsh \& Crompton (1995: 326) cited same specimens as holotype (at NY) and isotypes [at US, and UT; Welsh \& Crompton (l.c.) also at GH] of Atriplex garrettii [indication by Welsh \& Crompton (l.c.) is "Type: Utah, Crand Co., Vicinity of Moab, July 1-2, 1911, P. A. Rydberg \& A. O. Garrett 8465; holotype NY!; isotypes GH!, US!, UT!”]. Both Sanderson \& Stutz (2001: 79) and Welsh \& Crompton (1995: 326) correctly denoted the type categories for type specimens of this taxon.

Welsh \& Crompton (1995: 326) also proposed the new combination Atriplex garrettii var. navajoensis (C. A. Hanson) Welsh \& Crompton, pointing out morphological differences between it and var. garrettii in both vegetative and generative characters.

\subsubsection{Atriplex nuttallii}

Watson (1874: 116) seemingly proposed Atriplex nuttallii as a replacement name for $A$. canescens (Pursh) Nutt. by the citation of "Atriplex canescens. Nuttal, Genera, 1 . 197; not of James". However, Watson's reference to James for Atriplex canescens means the exclusion of its type. As a consequence, $A$. nuttallii is not an illegitimate replacement name of Atriplex canescens. A same conclusion can be made concerning the second synonym cited by Watson (1874: 116), i.e. "Obione canescens. Moquin, Enum. Chenop. 74" which was not correctly cited, maening "Obione canescens sensu Moq. non O. canescens (Pursh) Moq.”. As regard Watson's synonym "Atriplex Gordoni. Hook. Pl. Geyer in Lond. Jour. Bot. 5. 261?", his name is to be intended as a correction of "gardnerii" for Obione gardnerii Moq. since collector of type material was Gordon not Gardner (see also McNeill \& al. 1983: 553-554). However, althought Moquin's error was not nor orthographic neither typographic, original spelling should be retained. As Atriplex gardnerii (Moq.) A. Dietr. (三Obione gardnerii Moq. - Atriplex gordoni sensu Watson) is legitimate, Atriplex nuttallii is superfluous (Art. 52.2). McNeill $\&$ al. (l.c.) typified the Watson' name on a specimen deposited at K. Stutz \& Sanderson (1998: 203) cited a GH specimen (part of the original material) as "lectotype". Altought their lectotypification is correct, it is superseded by those of McNeill \& al. (l.c.), and GH specimen is to be considered as a sintype. Moreover, we found two further specimens that can be considered as part of original material (YU068871, and YU068874) bearing plants collected, respectively, by E. Hall \& J. P. Harbour and by S. Watson in United States before 1874 (original collection numbers are 308 and 981, as indicated in the protologue). These YU specimens are syntypes too.

\subsubsection{Calligonum canescens}

Calligonum canescens was validly proposed by Pursh (1813: 370) by a diagnosis, the provenance ("In the plains of the Missouri, near the Big-bend"), and the citation "v. s. [= vidi sicco] in Herb. Lewis".

Sanderson \& Stutz (2001: 78) reported, as "holotype", a specimen preserved at $\mathrm{PH}$, and collected by Lewis in Big bend of the Missouri (South Dakota) in 21 september 1804. Based on Art. 9.10 this holotype indication should be corrected to lectotype. However, previously McNeill \& al. (1983: 553) correctly designated as lectotype at the same $\mathrm{PH}$, and their lectotypification is to be considered as valid.

\subsubsection{Obione occidentalis var. angustifolia and $A$. angustior}

Obione occidentalis var. angustifolia was described by Torrey (1859: 184) through a very short diagnosis ("foliis angusto-linearibus vel lanceolato-linearibus"); some specimens (syntypes, Art. 9.6) were also cited ("Valley of the Rio Grande, from El Paso to 40 miles below San Elceario Bigelow, Wright. On the Gila; Thurber (No. 1742, Wright"). 
Sanderson \& Stutz (2001: 78) reported "Type: Valley of the Rio Grande from El Paso to 40 miles below San Elceario, Wright 1742 (lectotype NY)". According to the Art. 7.11 of ICN "... designation of a type is achieved only ..., on or after 1 January 2001, if the typification statement includes the phrase "designated here" (hic designatus) or an equivalent". As a consequence, the lectotype indication by Sanderson \& Stutz (l.c.) cannot be considered as valid.

Welsh \& Crompton (1995: 332) for Obione occidentalis var. angustifolia, wrote: "Type: Field No. 394. Obione, Sandy ridge on Rio Grande, 3-5 ft tall, much branching, June 17, 1852. Rio Grande below El Paso Texas. [Wright] 1742 = 394"; holotype NY!; isotypes GH! (3 sheets). Under Art. 9.10 of the ICN, Welsh \& Crompton's use of the term "holotype" is an error to be corrected to lectotype (NY specimen), while the GH specimen is an isolectotype.

Cockerell (in Scudder \& Cockerell 1902: 7) validly proposed Atriplex angustior as a new name for Obione canescens var. angustifolia Torr. (see Art. 11.2).

According to Welsh (2003) and Welsh \& Crompton (1995), this varietal name is to be regarded as a synonym of var. canescens.

\subsubsection{Pterochiton occidentale}

Torrey \& Frémont (1845: 318) described Pterochiton occidentale through a detailed diagnosis, also giving the habitat (“... vegetation of saline soils of the west ...”). The authors also stated "The precise locality of this plant we cannot indicate, as the label was illegible; but it was probably from the borders of the Great Salt Lake".

Welsh \& Crompton (1995: 333) cited the following type information for Pterochiton occidentale: "Type: Pterochiton occidentale Torr. \& Frem.n Fremont, probably 10 September 1843 [locality data are missing from the type specimen] (holotype NY!; microfiche BRY!)”. Welsh \& Crompton (l.c.) correctly denoted the type categories for type specimens of this taxon. We here consider the Welsh $\&$ Crompton's statement as a lectotypification.

\subsection{Taxonomic treatment}

The analysis of literature, herbarium investigations, and comparison of the protologues allowed to correct the previous holotype statements proposed by Welsh \& Crompton (1995) to lectotypes for all the Atriplex names investigated in the present paper. A nomenclatural treatment of $A$. canescens s. lat. (four varieties), and $A$. garrettii s. lat. (two varieties) follows.
Atriplex canescens (Pursh) Nutt., Gen. N. Amer. Pl. 1: 197. 1818 var. canescens $\equiv$ Calligonum canescens Pursh, Fl. Amer. Sept. 2: 370. $1813 \equiv$ Obione canescens (Pursh) Moq., Chenopod. Monogr. Enum.: 74. $1840 \equiv$ Pterochiton canescens (Pursh) Nutt., J. Acad. Nat. Sci. Philadelphia, ser. 2 1: 184. 1848. - Lectotype (designated by McNeill \& al. 1983: 553): South Dakota, Big bend of the Missouri, 21. IX. 1804, Lewis s.n. (PH-LC-34! [righthand fragment], image of the lectotype available at http:// www.plantsystematics.org/reveal/pbio/LnC/atricane. html).

= Atriplex nuttallii S. Watson, Proc. Amer. Acad. Arts 9: 116. 1874 - Lectotype (designated by McNeill \& al. 1983: 554): Saskatchewan, Prairie, assez rare, 18. IX. 1857, Bourgeau s.n. (K) - Syntypes [U.S.A., Nevada, VII. 1868, Watson 981 (GH-00036881); U.S.A., Nevada, Unionville Valley, VI.1868, Watson 981 (YU-068874!, image available at http://plants.jstor.org/stable/10.5555/ al.ap.specimen.yu068874? searchUri=scope $\% 3$ Dplants $\%$ 26so $\% 3 \mathrm{Dps}$ group_by genus_species $\% 2 \mathrm{Basc} \% 26 \mathrm{Que}$ ry\%3DSpecies\%3Anuttallii\%2520AND\%2520Genus \%3AAtriplex\%2520AND\%2520\%28raw_type\%3Avisu al\%2520OR\%2520ResourceType $\% 3$ Aspecimens $\% 29$ ); U.S.A., Colorado and Nebraska, 1862, Hall \& Harbour 308 (YU-068871!, image available at http://plants.jstor. org/stable/10.5555/al.ap.specimen.yu068871?searchUri =scope $\% 3$ Dplants $\% 26$ so $\% 3$ Dps_group_by_genus_spec ies\%2Basc\%26Query\%3DSpecies\%3Anuttallii\%2520A ND\%2520Genus\%3AAtriplex\%2520AND\%2520\%28 raw_type\%3Avisual\%25200R\%2520ResourceType \%3 Aspecimens\%29).

$=$ Atriplex canescens var. occidentalis (Torrey \& Frémont) S.L.Welsh \& Stutz, Great Basin Naturalist. 44: 189. 1984 $\equiv$ Pterochiton occidentale Torr. \& Frém., Rep. Calif.: 318. $1845 \equiv$ Atriplex occidentalis (Torr. \& Frém.) D. Dietr., Syn. Pl. 5: $537.1852 \equiv$ Obione occidentalis (Torr. \& Frém.) Moq., Prodr. [DC] 13(2): 112-113. 1849 Lectotype [designated by Welsh \& Crompton 1995: 333 (as "holotype", here corrected according to the Art. 9.10)]: U.S.A. California, probably 10.X. 1943, s.coll. s.n. (NY-0008506!, image of the lectotype available at http://sweetgum.nybg.org/science/vh/specimen_details. php?irn=719719).

= Atriplex canescens var. angustifolia (Torr.) S. Watson, Proc. Amer. Acad. Arts 9: 121. $1874 \equiv$ Obione canescens var. angustifolia Torr., Rep. U. S. Mex. Bound. 2(1): 184. 1859 E Atriplex angustior Cockerell, Proc. Davenport Acad. Nat. Sci. 9: 7. 1902 - Lectotype [designated by Welsh \& Crompton 1995: 332 (as "holotype", here corrected according to the Art. 9.10)]: U.S.A. Texas, Rio Grande below El Paso, Sandy ridge on Rio Grande, 17. VI. 1852, Wright 1742 (NY-00006460!, 
image of the lectotype available at http://sweetgum. nybg.org/science/vh/specimen_details.php?irn=65599). - Isolectotypes GH-00037218, GH-00037218, images of the isolectotypes available respectively at https:// s3.amazonaws.com/huhwebimages/40F64A55E63F4B1/ type/full/37218.jpg, and https://s3.amazonaws.com/ huhwebimages/6837764347BE4E6/type/full/37219. jpg).

- Obione canescens (Pursh) Torr., Rep. Exped. Rocky Mts.: 95. 1845, isonym (Art. 6.3 Note 2).

- Atriplex heterophylla Nutt. ex Moq., Prodr. [DC] 13(2): 112-113. 1849, nom. inval. (Art. 36.1b).

- Atriplex fruticosa Nutt. ex Moq., Prodr. [DC] 13(2): 112-113. 1849, nom. inval. (Art. 36.1b).

- Lophocaria spinosa Nutt. ex Moq., Prodr. [DC]13(2): 112-113. 1849, nom. inval. (Art. 36.1b).

- Pterocaria spinosa Nutt. ex Moq., Prodr. [DC]13(2): 112-113. 1849, nom. inval. (Art. 36.1b).

- Atriplex canescens (Pursh) Brandegee, Proc. Calif. Acad. Sci. ser. 2, 2: 200. 1889, isonym (Art. 6.3 Note 2).
Atriplex canescens var. gigantea S.L. Welsh \& Stutz, Great Basin Naturalist. 44: 189. 1984 (Fig. 1) - Holotype: U.S.A. Utah, Haub County, Lynndyl sand dunes, 08 september 09-1965, Welsh \& Moore 5126 (BRY0000376!, image of the holotype available at http://intermountainbiota.org/portal/collections/individual/index. php?occid=3859583\&clid=0). - Isotype NY-00006452!, image of the isotype available at http://sweetgum.nybg. org/science/vh/specimen_details.php?irn=278081

Description: Shrubs, dioecious, 10-18 dm, not armed. Leaves persistent, alternate, sessile or shortly petioled (petiole 1-4 mm long), blade mostly linear, (16-)20$40(-45) \times(4-) 5-6(-7) \mathrm{mm}$, margin entire, apex obtuse, green, pubescent of both surfaces. Staminate flowers arranged in clusters (about $3 \mathrm{~mm}$ wide), the clusters forming panicles-like structures (up to $15 \mathrm{~cm}$ long). Pistillate flowers arranged in panicles-like inflorescence, $8-14 \mathrm{~cm}$ long. Fruiting bracts-like cover $15-30 \mathrm{~mm}$ wide, on stipes up to $8 \mathrm{~mm}$ long, with 4 wings extend-

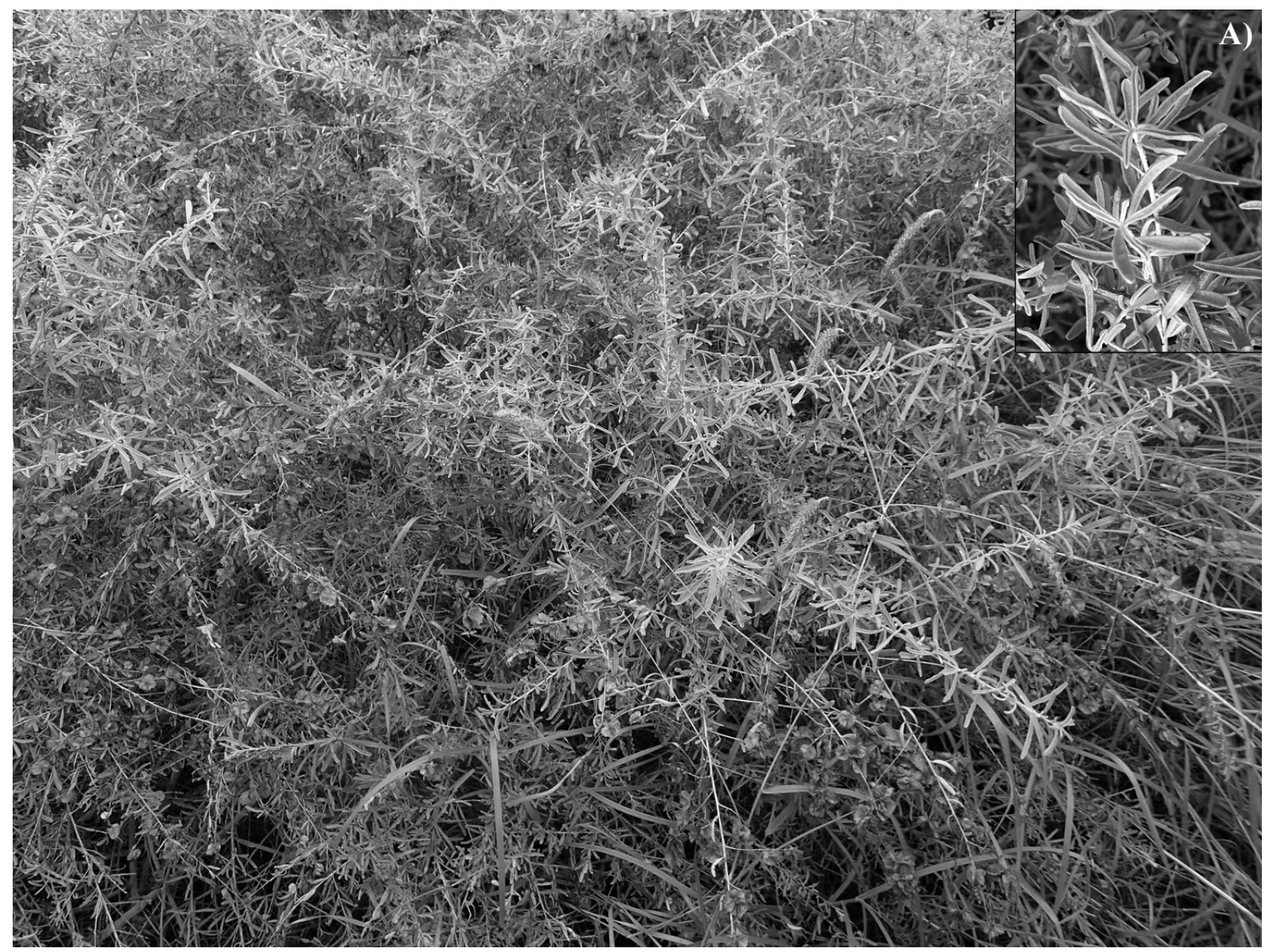

Figure 1: Atriplex canescens var. giganted at Medenine, southern Tunisia (photo by R. El Mokni). A) details of leaves. Slika 1: Atriplex canescens var. gigantea pri mestu Medenine, južna Tunizija (foto R. El Mokni). A) podrobnosti listov. 
ing the bract length, wings being irregulary dentate (apical teeths with an erect awn, 2-4 mm long), with smooth or reticulate surfaces. Seeds $1.5-2.5 \mathrm{~mm}$ wide.

Phenology: flowering and fruting times OctoberDecember.

Habitat: roadsides and cultivated land (central $\mathrm{Tu}-$ nisia), rehabilitated steppes (southern Tunisia), at $0-16 \mathrm{~m}$ a.s.l.

Distribution in Tunisia: 3 populations (22-24 individuals in total) were found in the following localities: Lamta (5-6 individuals covering an area of about 100 $\mathrm{mq}$ ), Medenine (2-3 individuals covering about 60 $\mathrm{mq}$ ), Bouficha-Enfida (22 individuals covering about $60 \mathrm{mq}$ ) (Fig. 2).

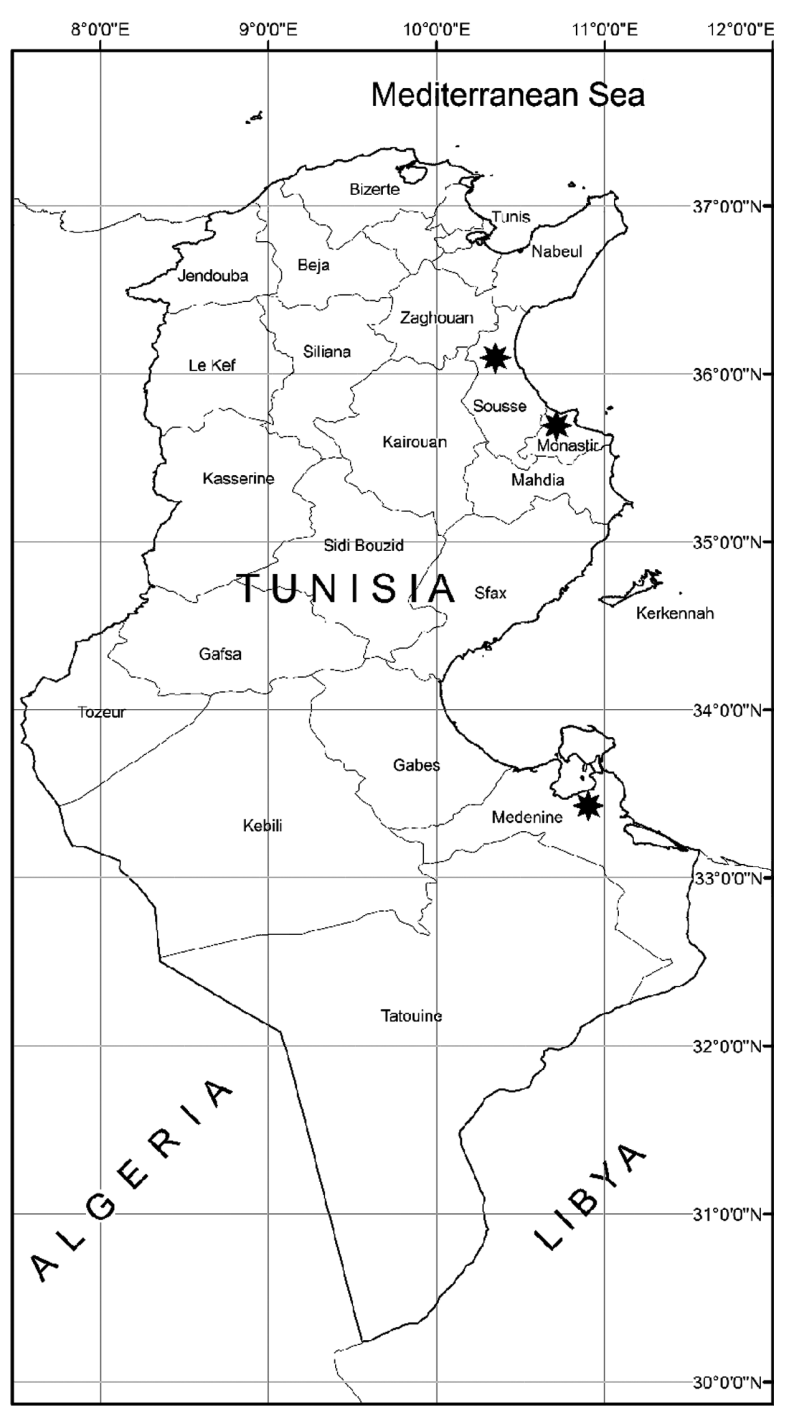

Figure 2: Distribution map of Atriplex canescens var. gigantea in Tunisia (*). Slika 2: Karta razširjenosti taksona Atriplex canescens var. gigantea v Tuniziji $\left(^{*}\right)$.
Native range and status of naturalization in Tunisia: Atriplex canescens s.lat. (four varieties recognized by Welsh 2004) is a neophyte species native to N-America and Mexico, while it is an alien in Africa (SANBI 2012), western and south-eastern Australia (Atlas of Living Australia 2016), eastern Asia (see e.g., Freitag et al. 2001), and Eastern Mediterranean area (Israel/ Palestine: A. Sukhorukov, pers. obs.).

The three populations of $A$. canescens var. gigantea discovered in Tunisia (see above "Distribution in Tunisia") were first observed in 2015 (last observations in January 2017). According to Pyšek et al. (2002), A. canescens should be treated as a casual alien species in Tunisia. However, in 2015 the areas of occupancy were about the same of those observed later, so plants would have occurred also before 2015. Moreover, if we consider that 1) areas of occupancy are wide (60-100 mq), and 2) plants are perennial (and so they remain alive for more than two years), we can propose $A$. canescens as a naturalized species.

Taxonomic notes: on the basis of the descriptions given by Welsh (2004), the plants discovered in Tunisia clearly refer to Atriplex canscens var. gigantea showing the following characters: high of plants $10-18 \mathrm{dm}$, width of leaves blades (4-)5-6(-7) $\mathrm{mm}$, margins of the fruiting bracts-like cover irregulary dentante (Fig. 3), width of the fruiting bracts-like cover $15-30 \mathrm{~mm}$. An interesting character, which is not mentioned by Welsh (2004) in Flora of North America, North of Mexico, is the apex of the apical teeths in fruiting bracts-like cover, which are awned in the Tunisian plants (awns 2-4 mm long) (Fig. 3). Actually, the types (lecto- and iso-) of the var. canescens do not show this feature, while one of the holotype of the var. gigantea (BRY-0000376) bears two pieces of a plant with at least some fruiting bracts-like cover having the apical teeths awned. Our description so amends that reported in the North American flora.

Specimina visa: Tunisia: Monastir (Lamta, Center east), small population in the coastal road to Bouhjar, $35^{\circ} 40^{\prime} 38^{\prime \prime} \mathrm{N}, 10^{\circ} 52^{\prime} 44^{\prime \prime} \mathrm{E}, 0-1 \mathrm{~m}$ a.s.l., 09. XI. 2015, R. El Mokni s.n. (Herb. Univ. Monastir). Medenine (El Fjè, South east), sporadic specimens in some rehabilitated steppes, 3329'59” N, 10³8'29” E, 14-16 m a.s.l., 18. X. 2016, R. El Mokni s.n. (HFLA, Herb. El Mokni). Sousse (Bouficha-Enfidha, Center east), along some edges of Lycium on roadsides, $36^{\circ} 22^{\prime} 08^{\prime \prime} \mathrm{N}$, 10³0’40” E, 11-13 m a.s.l., 06. I. 2017, R. El Mokni s.n. (Herb. El Mokni). 


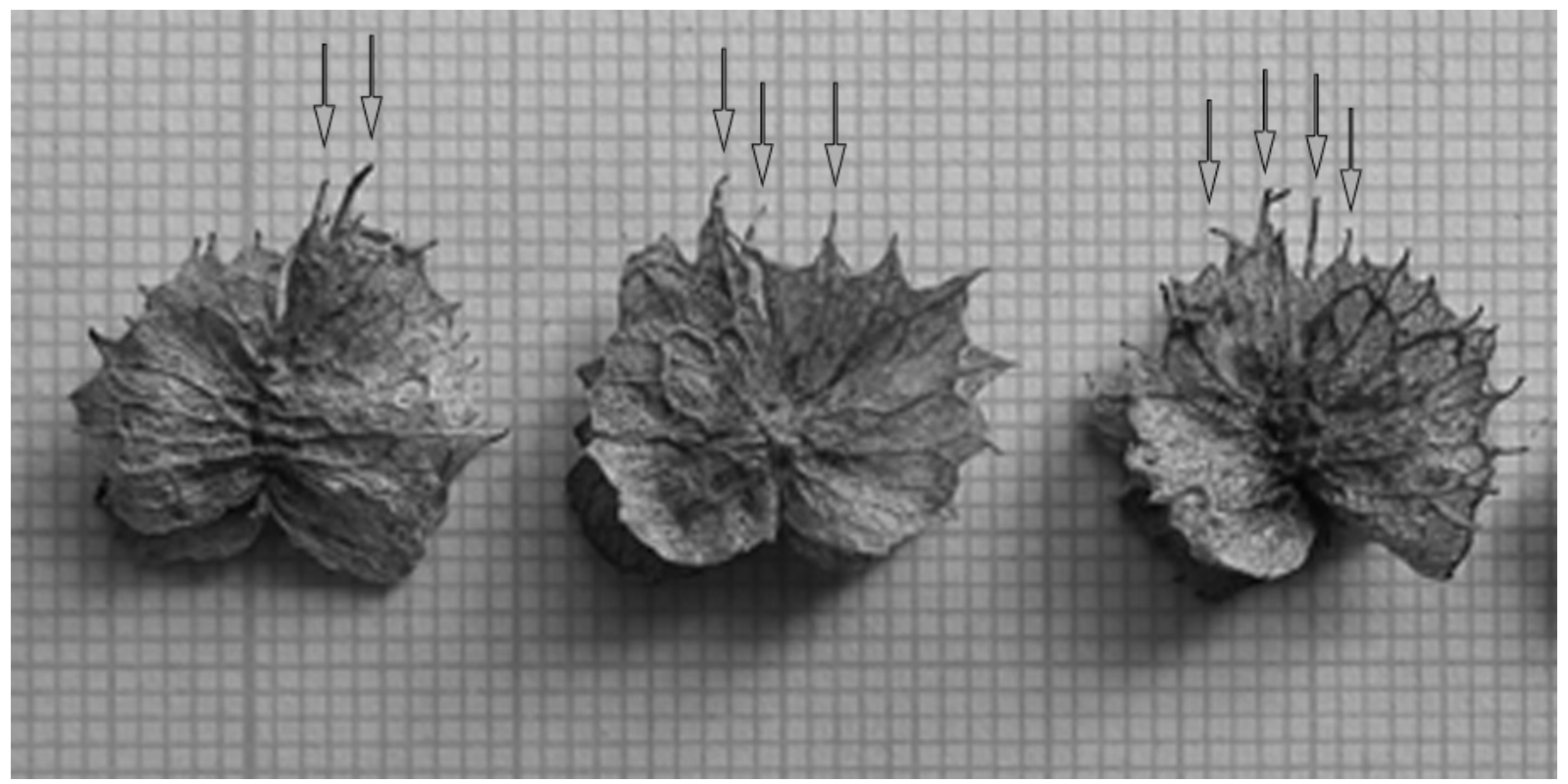

Figure 3: Details of fruiting bracts-like cover in Atriplex canescens var. gigantea (from a specimen collected at Lamta, central Tunisia; photo by R. El Mokni). Arrows indicate the awns of apical teeth.

Slika 3: Podrobnosti plodečih podpornih listov pri Atriplex canescens var. gigantea (pri primerku, nabranem pri mestu Lamta, osrednja Tunizija; foto R. El Mokni). Puščice kažejo rese vršnih zobcev.

Atriplex canescens var. laciniata Parish in Jepson, Fl. Calif. 1: 442. 1914 - Lectotype [designated by Welsh \& Crompton 1995: 324 (as "holotype", here corrected to lectotype according to the Art. 9.10)]: U.S.A. California, Salton Basin, Caleb, 11. X. 1912, Parish 8256 (JEPS-8934!, image of the lectotype available at http://plants.jstor.org/stable/10.5555/al.ap.specimen. jeps8934); isolectotypes CAS-0027906! (image available at http://plants.jstor.org/stable/10.5555/al.ap. specimen.cas0027906), and GH-00036871! (image available at https://s3.amazonaws.com/huhwebimages/ A4D594885C90455/type/full/36871.jpg).

Atriplex canescens var. macilenta Pursh in Jepson, Fl. Calif. 1: 442. 1914 - Lectotype [designated by Welsh \& Crompton 1995: 324 (as "holotype", here corrected according to the Art. 9.10)]: U.S.A. California, Salton Basin, Bluffs of Alamo River, Holtville, 18. X. 1912, Parish 8258 (JEPS-2762!, image of the lectotype available at http://plants.jstor.org/stable/10.5555/al.ap.specimen.jeps2762); isolectotypes CAS-0027907! (image available at http://plants.jstor.org/stable/10.5555/al.ap. specimen.cas0027907), DS (fide Welsh \& Crompton 1995: 324), GH-00036872! (image available at https:// s3.amazonaws.com/huhwebimages/1CEB9F6201474A4/ type/full/36872.jpg), and POM (fide Welsh \& Crompton 1995: 324).
Atriplex garrettii Rydb., Bull. Torrey Bot. Club 39(7): 312. 1912 var. garrettii $\equiv$ Atriplex canescens subsp. garrettii (Rydb.) H.M. Hall \& Clem., Publ. Carnegie Inst. Wash. 326: 344. 1923 EAtriplex canescens var. garrettii (Rydb.) L.D. Benson, Amer. J. Bot. 30(3): 236. 1943 - Lectotype [designated by Welsh \& Crompton 1995: 326 (as "holotype", here corrected according to the Art. 9.10)]: U.S.A., Utah, Moab and vicinity, 01. VII. 1911, Rydberg \& Garrett 8465 (NY-00006433!, image available at http://sweetgum.nybg.org/science/vh/specimen_details.php?irn=694092); isolectotypes US-00102603!, image available at http://collections.nmnh.si.edu/search/ botany/; UT (fide Welsh \& Crompton 1995: 324).

Atriplex garrettii var. navajoensis (C.A. Hanson) S. L. Welsh \& Crompton, Great Basin Naturalist. 55: 326. $1995 \equiv$ C.A. Hanson, Stud. Syst. Bot. 1:3. 1962 - Holotype: U.S.A., Arizona, Coconino County, E side of Navajo Bridge, 21. VII. 1971, Hanson 388 (BRY, isotypes GH00036880!, and RSA-0002451!, image of the isolectotypes available respectively at https://s3.amazonaws.com/ huhwebimages/900056079E854B6/type/full/36880. jpg, and http://plants.jstor.org/stable/10.5555/al.ap.specimen.rsa0002451?searchUri=plantName $\% 3 \mathrm{D} \% 2522 \mathrm{At}$ riplex $\% 2$ Bnavajoensis $\% 2522 \% 26$ syn $\% 3 \mathrm{D} 1$ ). 


\subsection{Diagnostic key for Atriplex canescens s. I. and A. garrettii}

A diagnostic key for 4 varieties of $A$. canescens, and 2 varieties of $A$. garrettii is provided below.

1. Leaves $>8 \mathrm{~mm}$ wide, bracts-like cover tip with or without teeths 2

- Leaves up to $8 \mathrm{~mm}$ wide; bracts-like cover tip without lateral teeths...... 3

2. Plants $2-6 \mathrm{dm}$ tall; leaves up to 9 in the first flowering branch; staminate flower usually brown.

- Plants 5-10 dm tall; leaves $\geq 7$ in the first flowering branch; staminate flower usually yellow.

Atriplex garrettii var. garrettii

3. Fruiting bracts-like cover dentate to entire, $8-25 \mathrm{~mm}$ wide Atriplex garrettii var. navajoensis

- Fruiting bracts-like cover dentate to laciniate, 5-10 mm wide 4

4. Fruiting bracs-like cover $<12 \mathrm{~mm}$ wide. .5

- Fruiting bracs-like cover $>15 \mathrm{~mm}$ wide.

Atriplex canescens var. canescens Atriplex canescens var. gigantea

5. Shrubs 3-10 dm high, fruiting bracts-like cover 4-8 mm wide, dentate or laciniate.

- Shrubs 10-20 dm high, fruiting bracts-like cover 8-11 mm wide, laciniate.

Atriplex canescens var. macilenta Atriplex canescens var. laciniata

\section{Acknowledgements}

Thanks are due to Directors and Curators of all quoted public herbaria and colleagues of the cited personal herbaria for their support during our visits, loan of specimens/photographs or for providing interesting information. We are also grateful to M. Neffati (I.R.A. Medenine) who gave us the opportunity to have a large field trip in some steppes of southern Tunisia and to M. Tarhouni (I.R.A. Medenine) who provide us with several fresh samples for deeply examination of the infraspecific taxa.

Duilio lamonico (D), https://orcid.org/0000-0001-5491-7568 Ridha El Mokni (D), https://orcid.org/0000-0003-3849-1039

\section{References}

APG IV 2016: An update of the Angiosperm Phylogeny Group classification for the orders and families of flowering plants: APG IV. Bot. J. Linn. Soc. 181: 1-20.

Atlas of living Australia 2016+: Atriplex canescens (Pursh) Nutt. http:// bie.ala.org.au/species/http://id.biodiversity.org.au/node/apni/2910967 (last accessed 04 February 2017).

Bassett, I. J., Crompton, C. W., McNeill, J. \& Tachereau, P. M. 1983: The genus Atriplex (Chenopodiaceae) in Canada. Ministry of Supply and Services Canada, Ottawa.

Brignone, N.F., Denham, S.S. \& Pozner, R. 2016: Synopsis of the genus Atriplex (Amaranthaceae, Chenopodioideae) for South America. Australian Systematic Botany 29: 324-357. http://doi.org/10.1071/ SB16026
Franclet, A. \& Le Houérou, H. N. 1971: Les Atriplex en Tunisie et en Afrique du Nord. FAO-Institut de reboisement, Rome.

Freitag, H., Hedge, I.C., Jafri, S.M.H., Kothe-Heinrich, G., Omer, S. \& Uotila, P. 2001: Atriplex L. In: Ali, S.I \& Qaiser, M. (eds.): Flora of Pakistan 204. University of Karachi, Karachi \& Missouri Botanical [Garden] Press, St. Louis, pp. 54-70.

Iamonico, D. 2012: Studies on the genus Atriplex L. (Amaranthaceae) in Italy. II. Lectotypification of Atriplex elongata Guss.

(Amaranthraceae). Candollea 67(1): 181-185.

Iamonico, D. 2013: Studies on the genus Atriplex L. (Amaranthaceae) in Italy. V. Atriplex tornabenei. Phytotaxa 145(1): 54-60. http://dx.doi. org/10.11646/phytotaxa.145.1.6

Iamonico, D. \& Sukhorukov, A.P. 2014: Studies on the genus Atriplex (Chenopodiaceae) in Italy. VI. Names by Michele Tenore: Atriplex axillaris, $A$. diffusa, and A. polysperma. Hacquetia 13(2): 285-296. http://doi.org/10.2478/hacq-2014-0005.

Iamonico, D. \& El Mokni, R. 2017: Amaranthus palmeri (Amaranthaceae) in Tunisia, a second record for the continental African flora and nomenclatural notes on $A$. sonoriensis nom. nov. pro A. palmeri var. glomeratus. Bothalia 47(1): a2100. https://doi.org/10.4102/abc. v47i1.2100

James, E. P. 1825: Catalogue of Plants Collected during a Journey to and from the Rocky Mountains, during the summer of 1820. Trans. Amer. Philos. Soc., ser. 2, 2: 172-190.

Jepson, W. L. 1914: A Flora of California 1(4). San Francisco.

Kadereit, G., Mavrodiev, E.V., Zacharias, E.H. \& Sukhorukov, A. P. 2010: Molecular phylogeny of Atripliceae (Chenopodioideae, Chenopodiaceae): Implications for systematics, biogeography, flower and fruit evolution, and the origin of $\mathrm{C}_{4}$ photosynthesis. Amer. J. Bot. 97(10): 1664-1687. 
McNeill, J., Bassett, I. J., Crompton, C. W. \& Taschereau, P. 1983. Taxonomic and nomenclatural notes on Atriplex L. (Chenopodiaceae). Taxon 32: 549-556.

Pyšek, P., Richardson, D.M., Rejmanek, M., Webster, G. L., Williamson, M. \& Kirschner, J. 2002: Alien plants in checklists and floras: towards better communication between taxonomists and ecologists. Taxon 53: 131-143. http://dx.doi.org/10.2307/4135498

Rydberg, P.A. 1912: Studies of the Rocky Mountain flora-XXVII. Bull. Torrey Bot. Club 39(7): 301-328.

SANBI 2012: Atriplex canescens (Pursh) Nutt. In: National Assessment: Red List of South African Plants version 2014.1. http://www.ville-ge. $\mathrm{ch} / \mathrm{musinfo} / \mathrm{bd} / \mathrm{cjb} / \mathrm{africa} /$ details.php?langue=an\&id=131459 (last accessed 04 February 2017).

Sanderson, S.C., Stutz, H.C. 2001: Chromosome races of Fourwing Saltbush (Atriplex canescens), Chenopodiaceae. In: McArthur, E.D.; Fairbanks, D.J. (comps.): Shrubland ecosystem genetics and biodiversity (Proceedings, 13-15June 2000). Provo, UT. Proc. RMRS-P-21. Ogden, UT: U.S. Department of Agriculture, Forest Service, Rocky Mountain Research Station, pp. 75-88.

Scudder, S.H. \& Cockerell, T.D.A. 1902: A first list of the Orthoptera on New Mexico. Proc. Davenport Acad. Nat. Sci. 9: 1-60.

Stutz, H.C. \& Sanderson, S.C. 1998: Taxonomic clarification of Atriplex nuttallii (Chenopodiaceae) and its near relatives. Sida, Contributions to Botany 18: 193-212.

Sukhorukov, A.P. \& Danin, A. 2009: Taxonomic notes on Atriplex sect. Teutliopsis and sect. Atriplex in Israel and Syria. Fl. Medit. 19: 15-23.

Sukhorukov, A.P. Martín-Bravo, S., Verloove, F., Maroyi, A., Iamonico, D., Catarino, L., El Mokni, R., Daniel, T.F., Belyaeva, I.V. \& Kushunina, M. 2016: Chorological and taxonomic notes on African plants. Bot. Lett. 163(4): 417-428. http://dx.doi.org/10.1080/238181 07.2016.1224731
Thiers, B. 2018+: Index Herbariorum: A global directory of public herbaria and associated staff. New York Botanical Garden's Virtual Herbarium. http://sweetgum.nybg.org/ih/ (last accessed 04 February 2017).

Torrey, J. 1859: Botany of the boundary. In: Emory, W.H. (ed.): United-States and Mexican boundary survey. Rep. U.S. Mex. Bound 2(1): 227-236.

Torrey, J. \& Frémont, J.C. 1845: Report of the Exploring Expedition to the Rocky Mountains in the year 1842. Gales and Seaton, Washington.

Turland N.J., Wiersema J.H., Barrie F.R., Greuter W., Hawksworth D.L., Herendeen P.S., Knapp S., Kusber W.-H., Li D.-Z., Marhold K., May T.W., McNeill J., Monro A.M., Prado J., Price M.J., Smith G.F. International Code of Nomenclature for algae, fungi, and plants (Shenzhen Code) adopted by the Nineteenth International Botanical Congress Shenzhen, China, July 2017. Regnum Vegetabile, 2018, 159: i-xxxviii + 1-254. https://doi.org/10.12705/Code.2018.

Uotila, P. 2011: Chenopodiaceae (pro parte majore). In: Euro+Med Plantbase - the information resource for Euro-Mediterranean plant diversity. http://euromed.luomus.fi/euromed_map.php?taxon=450963 \&size=mediumWelsh (last accessed 04 February 2017).

Watson, S. 1874: A revision of the North American Chenopodiaceae. Proc. Amer. Acad. Arts 9 (vol. 1 of New Series): 82-126.

Welsh, S.L. 1984: Utah flora: Chenopodiaceae. Great Basin Naturalist 44(2): 183-209. Welsh, S.L. 2003: Atriplex L. In: Flora of North America Editorial Committee (eds.): Flora of North America North of Mexico 4 (Magnoliophyta: Caryophyllidae). Oxford University Press, New York \& Oxford, pp. 306-307.

Welsh, S.L. \& Crompton, C. 1995: Names and types of perennial Atriplex Linnaeus (Chenopodiaceae) in North America selectively exclusive of Mexico. Great Basin Naturalist 55(4): 322-334. Available at: https://scholarsarchive.byu.edu/gbn/vol55/iss4/4 